\title{
Improving salinity tolerance in Salvia officinalis L. by foliar application of salicylic acid
}

\author{
Fatima Zohra Es-sbihi ${ }^{*}$, Zakaria Hazzoumi ${ }^{2}$, Abderrahim Aasfar ${ }^{2}$ and Khalid Amrani Joutei ${ }^{1}$
}

\begin{abstract}
Background: Higher absorption and translocation of sodium ( $\mathrm{Na}$ ) and chlorine $(\mathrm{Cl})$ ions in plant tissue can lead to serious physiological and biochemical changes. However, salicylic acid (SA) is a natural signaling molecule responsible for the induction of environmental stress tolerance in plants. Spraying SA could provide protection against several types of stress such as salinity. This study aimed to show the influence of SA spraying ( 0.5 and $1 \mathrm{mM}$ ) on the damaging effects of $\mathrm{NaCl}$ toxicity $(150 \mathrm{mM})$ in Salvia officinalis L. plants.

Results: The results showed that salinity strongly inhibited the growth of aerial and root parts and this inhibition was accompanied by a significant decrease in the production of chlorophyll pigments (by 63\%). There was also a significant accumulation of $\mathrm{Na}$, mainly in the roots. This accumulation of $\mathrm{Na}^{+}$ions was accompanied by a decrease of calcium (Ca), potassium (K) and phosphorus (P) concentrations. However, SA mainly at $0.5 \mathrm{mM}$, greatly improved plant growth, essential oils and chlorophyll pigments synthesis. Besides, SA led to a decrease in Na content and an improvement in $\mathrm{Ca}, \mathrm{K}$ and $\mathrm{P}$ content in the leaves and roots. Salt stress decreased the essential oil yield from 1.2\% (control) to $0.4 \%$ (NaCl). Furthermore, gas chromatography-mass spectrometry analysis of essential oils exhibited that the 1,8-cineol, a-thujone, and camphor were identified as the main components of essential oils under all treatments. However, we noted in stressed plant treated or not with SA the appearance of the new majority compound thujanone. Salt stress decreased the major compounds content. SA spray under stress condition increased the content of major compounds compared to stressed plants untreated with SA. The histological study in scanning electron microscopy showed the peltate glands density decreased strongly under $\mathrm{NaCl}$ toxicity. However, SA application on stressed plants increased peltate glands density. On the other hand, the glands of stressed plants often show certain anomalies in the morphology: the first anomaly observed was the presence of glandular structures characterized by deformations in the form of small protuberances located on the head of the gland. The second, a less common abnormality is the morphological change in certain glands that change from a spherical to an ovoid shape. On another hand, all these anomalies were not detected in stressed plants sprayed with SA. Therefore, the absence of these anomalies under the effect of SA showed the repairing effect of this growth regulator.
\end{abstract}

Conclusion: The findings of the present work suggest that spraying of SA may be useful for improving the plant growth in $\mathrm{NaCl}$-contaminated areas.

Keywords: Salvia officinalis L., Saline stress, Salicylic acid, Growth

*Correspondence: Essbihi.fatimazohra@gmail.com

${ }^{1}$ Laboratory of Microbial Biotechnology and Bioactive Molecules, Faculty of Science and Technology Fez, Sidi Mohamed Ben Abdellah University,

Road of Imouzzer, B.P. 2202, Fez, Morocco

Full list of author information is available at the end of the article

\begin{abstract}
Background
Salinity is considered among the global environmental constraints caused either by the initial presence of salts in the soil, the water table or in irrigation water. It is a growing problem due largely to the increasingly arid climate. According to the FAO and the most recent estimates, it already affects more than 400 million hectares.
\end{abstract}

Springer Open

(c) The Author(s) 2021. This article is licensed under a Creative Commons Attribution 4.0 International License, which permits use, sharing, adaptation, distribution and reproduction in any medium or format, as long as you give appropriate credit to the original author(s) and the source, provide a link to the Creative Commons licence, and indicate if changes were made. The images or other third party material in this article are included in the article's Creative Commons licence, unless indicated otherwise in a credit line to the material. If material is not included in the article's Creative Commons licence and your intended use is not permitted by statutory regulation or exceeds the permitted use, you will need to obtain permission directly from the copyright holder. To view a copy of this licence, visit http://creativeco mmons.org/licenses/by/4.0/. The Creative Commons Public Domain Dedication waiver (http://creativecommons.org/publicdomain/ zero/1.0/) applies to the data made available in this article, unless otherwise stated in a credit line to the data. 
Saline stress negatively affects plant growth and productivity, leading to osmotic stress, specific ionic effects and nutritional imbalances [6]. In addition, salinity leads to photosystem dysfunction due to stomatal limitations and pigment disruption, limiting photosynthetic yield and inducing an oxidative explosion, which damages all kinds of molecules and membranebound systems [16].

Two main types of salinity tolerance mechanism: (1) one minimizes the entry of salt ions into the plant and cytoplasm and (2) another minimizes the level of stress through biochemical and molecular changes. To survive under conditions of salt stress, the plant synthesizes several chemicals as potential growth regulators, including phytohormons, antioxidants and osmolytes [7]. In addition, tolerance to salinity is widely sought to expand cultivation in these regions. Therefore, exogenous applications of growth regulators are effective in improving plant growth and yield under saline condition $[5,8]$. Among these regulators, we find the SA which occurs naturally in plants, involved in defense mechanisms through the regulation of certain physiological and biochemical processes $[23,29]$. It causes absorption and translocation of nutrients, stimulation of pigments photosynthetic synthesis, water and the antioxidant system regulation [5, 31, 35]. Several studies showed the remedial effect of SA on the harmful effects of salinity on $S$. officinalis [46] and other plants [3, 4, 22, 28, 38, 42].

Salvia officinalis is a pharmacologically active plant and is used in folk medicine around the world. Characterized with specific antioxidant, spasmolytic, antimicrobial, anti-hidrotic, astringent, and sensory activities. Several reports also indicate antigenotoxic and chemopreventive activities of different extracts of S. officinalis L. species. Its essential oil contains cineole, borneol, thujone, camphor, pinene and camphene $[18,26]$. Like other Lamiaceae, $S$. officinalis essential oil is located in specialized structures called glandular trichomes [26]. In Lamiaceae, functionally and according to their mode of secretion, glandular hairs can be classified into two main types, capitate and peltate. It will be match better to add a section about the impact of salt stress on essential oil yield, and composition, and also the impact of SA on this parameter. The capitate secretes their products to the outside through a single pore shortly after their production. In contrast, the peltate secrete their products progressively into a space formed by the rise of the cuticle and outwards after the cuticle burst.

In this study, we investigated the influence of SA on the toxic effects of salt stress in S. officinalis on plant growth and mineral uptake, density of secretory glands and chemical content of essential oil.

\section{Materials and methods}

\section{Plant material and growth conditions}

S. officinalis L. cuttings were taken from the botanical garden of the Faculty of Science and Technology, Fez. Each cutting included at least two nodes. Culturing was carried out in plastic pots ( $3 \mathrm{~kg}$ capacity) containing 5 plants per pot and grown in a greenhouse.

\section{$\mathrm{NaCl}$ and SA treatments}

After 30 days of plants transplantation (DAT), watering was performed with $\mathrm{NaCl}$. This $\mathrm{NaCl}$ dose was chosen because of a preliminary experiment showed that from $150 \mathrm{mM}$ $\mathrm{NaCl}$ induced growth inhibition of $S$. offocinalis. $\mathrm{NaCl}$ was applied weekly over 5 weeks ( $200 \mathrm{ml}$ per pot). SA ( 0.5 and $1 \mathrm{mM}$ ) was applied by foliar spray at 60 DAT (these SA concentrations were chosen based on a preliminary screening experience). Three SA sprays were performed at a weekly interval using a hand sprayer (100 $\mathrm{ml}$ per pot).

This experiment includes total six treatments: control, $0.5 \mathrm{mM}$ salicylic acid (SA $0.5 \mathrm{mM}), 1 \mathrm{mM}$ salicylic acid (SA $1 \mathrm{mM}), 150 \mathrm{mM} \mathrm{NaCl}(\mathrm{NaCl}), 150 \mathrm{mM} \mathrm{NaCl}+0.5 \mathrm{mM}$ salicylic acid $(\mathrm{NaCl}+$ SA $0.5 \mathrm{mM})$ and $150 \mathrm{mM} \mathrm{NaCl}+1 \mathrm{mM}$ salicylic acid $(\mathrm{NaCl}+\mathrm{SA} 1 \mathrm{mM})$. The experiment was performed in five replicate and sampling was done at 100 DAT.

\section{Dosage of chlorophyll total}

Fragments of leaves $(1 \mathrm{~g})$ were ground in a mortar previously placed in ice with a pinch of magnesium carbonate and $5 \mathrm{~g}$ of anhydrous sodium sulfate. Then, $10 \mathrm{ml}$ of $80 \%$ acetone were poured into the ground material, which was filtered on a Buchner, the residue was recovered in essays tubes. Further extractions were carried out with acetone to obtain a filtrate colorless (devoid of all traces of chlorophyll pigments) which the final volume was specified. OD measurements were made with a spectrophotometer at wavelengths of $663 \mathrm{~nm}$ to $645 \mathrm{~nm}$ for chlorophyll (a) and chlorophyll (b).

McKinney [34] established systems of equations that calculate the concentrations $\left(\mathrm{g} \mathrm{l}^{-1}\right)$ chlorophyll from absorbance at 663 and $645 \mathrm{~nm}$ of an extract of $80 \%$ acetone are:

$$
\begin{aligned}
& \text { Chlorophyll } \mathrm{a}=(0.0127 \text { OD 663 })-(0.00269 \text { OD 645 }) \\
& \text { Chlorophyll } \mathrm{b}=(0.0229 \text { OD 645 })-(6630.00468 \text { OD }) \\
& \text { Total chlorophyll }=(0.0202 \text { OD } 645)+(0.00802 \text { OD 663) }
\end{aligned}
$$

\section{$\mathrm{Na}$ and nutrients ( $\mathrm{K}, \mathrm{P}$ and $\mathrm{Ca}$ ) content}

Content of $\mathrm{Na}$ and minerals ( $\mathrm{K}, \mathrm{P}$ and $\mathrm{Ca}$ ) was determined according to Cottenie et al. [14]. The root and shoot samples of S. officinalis were dried at $100{ }^{\circ} \mathrm{C}$ for $48 \mathrm{~h} .100 \mathrm{mg}$ of dried plant was calcined at $450{ }^{\circ} \mathrm{C}$ for 
$12 \mathrm{~h}$ in a muffle furnace. The ash obtained was dissolved in $3 \mathrm{ml}$ of nitric acid $(0.1 \mathrm{~N})$ and then filtered through Whatman filter paper 540 hardened ashless. The volume was adjusted to $20 \mathrm{ml}$ with distilled water. Based on this solution, the assay was performed by inductively coupled plasma emission spectrometry (ICP-AES) to determine the content of $\mathrm{Na}$ and minerals $(\mathrm{K}, \mathrm{P}$ and $\mathrm{Ca})$.

\section{Environmental scanning electron microscope}

Microscopic observations of the fresh leaves were made using an environmental scanning electron microscope (Quanta 200, FEI Company). The microscope was equipped with a tungsten electron gun. Analyses were carried out under partial pressure of water vapour.

\section{Count of peltate glandular trichome}

Peltate glands counting was performed on the ventral side of the fresh leaves on a $1 \mathrm{~mm}^{2}$ area, taking into consideration the basal (near the petiole), central and apical areas of the leaf. For each treatment, the glands number represents the average of glands of five plants and three leaves per plant [12].

\section{Essential oil extraction}

Essential oil extraction was carried out by hydrodistillation (Clevenger apparatus) of $100 \mathrm{~g}$ of parts aerial of $S$. officinalis dried in the free area. The extraction was carried out in $2 \mathrm{l}$ of distilled water for $180 \mathrm{~min}$. The essential oil was collected, dehydrated with sodium sulfate and stored at $4{ }^{\circ} \mathrm{C}$. Essential oil yield was calculated by the following formula [25]:

$$
\mathrm{YEO}(\mathrm{ml} / 100 \mathrm{~g} \mathrm{DM})=(V / \mathrm{DM} \times 100)
$$

YEO: essential oil yield of DM. $V$ : the volume of essential oil collected (ml). DM: dry plant weight (g).

\section{Essential oil analysis by GC-MS}

Essential oil content was determined by gas chromatography (GC) (Agilent 7890A Series) coupled to mass spectrometry (MS) and equipped with a multimode injector, a BD-ASTMD 6584 column $(15 \mathrm{~m} \times 0.320 \mathrm{~mm} \times 0.1 \mu \mathrm{m})$ and ionization by electronic impact. The protocol consists of: $10 \mu \mathrm{l}$ of a solution of HE solubilized in chloroform was injected into the column by split mode 1:2 using helium as carrier gas at $4 \mathrm{ml} \mathrm{min}{ }^{-1}$. The ion source and quadruple temperatures were $230{ }^{\circ} \mathrm{C}$ and $150{ }^{\circ} \mathrm{C}$, respectively. The oven temperature program was started at $30{ }^{\circ} \mathrm{C}$ and maintained $1 \mathrm{~min}$ then increased at $2{ }^{\circ} \mathrm{C} \min ^{-1}$ until $75{ }^{\circ} \mathrm{C}$ and maintained one minute then increased by $8{ }^{\circ} \mathrm{C} \mathrm{min}{ }^{-1}$ until $210{ }^{\circ} \mathrm{C}$ and kept constant for $1 \mathrm{~min}$. The composition of the essential oil determined from the peak areas was calculated as a percentage of the total compounds existing in the sample detection using full scan mode between 30 and $1050 \mathrm{~m} \mathrm{z}^{-1}$ with gain factor 5 and the identification was performed using NIST 2014 MS Library.

\section{Statistical analysis}

One-way analysis of variance was carried out for each parameter studied. Tukey's post hoc multiple mean comparison test was used to test for significant differences between treatments $(P \leq 0.05)$. Univariate analysis was used to test significant differences in treatments, accessions, and their interaction for an individual parameter. All statistical analyses were performed with IBM. SPSS statistics, Version 22. The results of each experiment (biochemical assays) were repeated three times (20 times for morphological assays).

\section{Results}

\section{Plant growth}

SA increased stem and root length mainly at $0.5 \mathrm{mM}$ (Fig. 1). Contrariwise, $\mathrm{NaCl}$ inhibited the growth of the aerial and root parts compared to control. This inhibition can reach $71 \%$ in the aerial part and $47 \%$ in the root part compared to the control. However, the SA application on stressed plants restored the lengths of the aerial and root parts mainly to $0.5 \mathrm{mM}$. This increase can reach almost $269 \%$ for the stem and $88 \%$ for the root compared to stressed plants untreated with SA.

\section{Chlorophyll content}

In the absence of salt stress, SA increased chlorophyll content mainly at $0.5 \mathrm{mM}$ (Fig. 2) by $79 \%$ compared to control. However, salt stress negatively affected

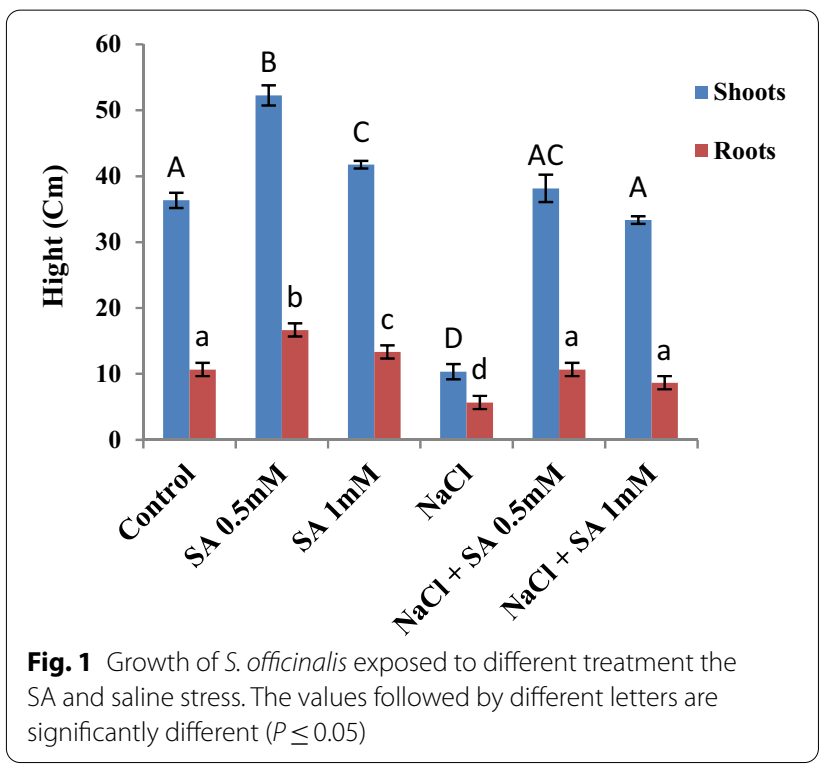


chlorophyll pigment synthesis by $64 \%$ compared to control plants (Fig. 2). On the other hand, SA spraying mainly at $0.5 \mathrm{mM}$ on stressed plants, accumulated a very high chlorophyll content which can reach about $800 \%$ more.

\section{$\mathrm{Na}, \mathrm{Ca}, \mathrm{K}$ and $\mathrm{P}$ accumulation}

Table 1 shows $\mathrm{Na}, \mathrm{Ca}, \mathrm{K}$ and $\mathrm{P}$ contents under the different treatment. In the absence of salt stress, SA influenced $\mathrm{Ca}$ and $\mathrm{K}$ accumulation in shoots and roots. Regarding $\mathrm{Ca}$, this accumulation was important at roots, while for $\mathrm{K}$, there was an increase in its absorption in roots and a

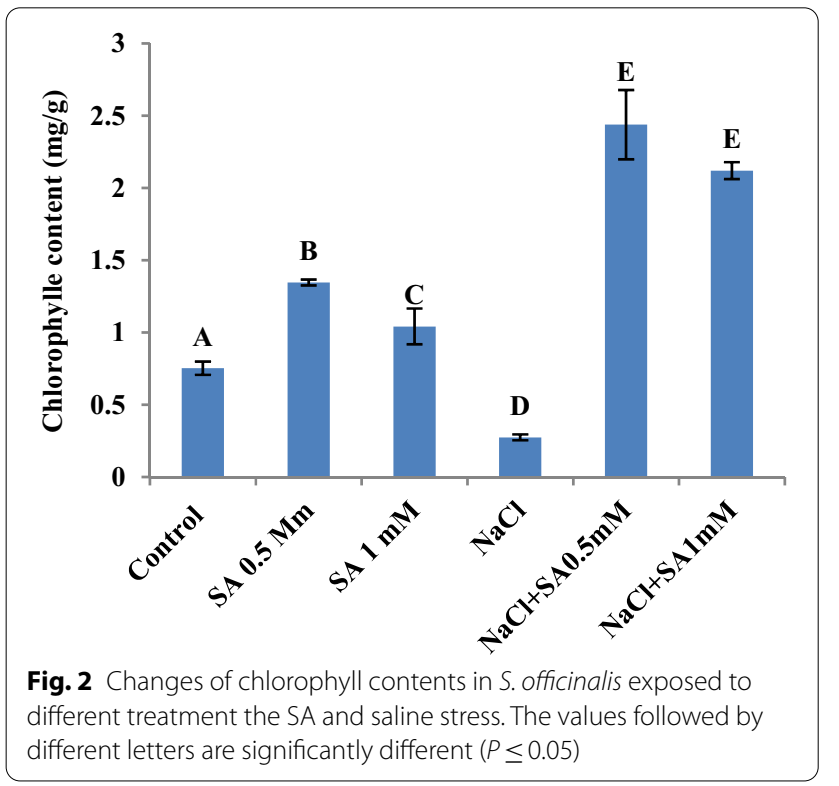

transfer of a significant amount to the leaves, mainly at $0.5 \mathrm{mM}$. On another hand, SA mainly at $0.5 \mathrm{mM}$, allows a significant absorption of $\mathrm{P}$ at roots without any transfer to the leaves.

Moreover, $\mathrm{NaCl}$ application considerably increased the sodium concentration in the various parts of the plant. This accumulation occurs mainly in the roots, but there was nevertheless a transfer of a fairly large amount in the leaves. In addition, salt stress caused a considerable drop in the various mineral elements both in the roots and in the leaves.

On saline stress conditions, SA application led to a reduction in the negative effects of the excess of $\mathrm{Na}^{+}$, since very low values were observed in roots and leaves mainly when SA was applied at $0.5 \mathrm{mM}$. These decreases can reach $83 \%$ and $76 \%$, respectively, in leaves and roots compared to stressed plants.

In addition, at this concentration of $0.5 \mathrm{mM}$, SA increased mineral element levels in the plant. Compared to stressed plants, these increases can reach $64 \%$ for Ca, $102 \%$ for $\mathrm{K}$ and $95 \%$ for $\mathrm{P}$ in the leaves, and $143 \%$ for $\mathrm{Ca}$, $108 \%$ for $\mathrm{K}$ and $81 \%$ for $\mathrm{P}$ at the roots.

\section{Glandular trichomes abundance}

Scanning electron microscopy observations showed the presence of trichomes abundance gradient along the leaf. SA increased glands density in all parts of the leaf. This increase was more pronounced at $1 \mathrm{mM}$ than $0.5 \mathrm{mM}$ (66\%, $95 \%$ and $70 \%$ against $33 \%, 52 \%$ and $41 \%$, respectively, for the basal, central and apical areas compared to the control) (Fig. 3).

On another hand, salt stress significantly decreased the peltate glands density in the three areas of the leaf

Table 1 Content of $\mathrm{Na}$ and mineral nutrients $\left(\mathrm{P}, \mathrm{K}^{+}, \mathrm{Ca}^{2+}\right)$ in $\mathrm{S}$. officinalis exposed to different treatments of SA and salinity stress in shoot and root

\begin{tabular}{|c|c|c|c|c|}
\hline & $\mathrm{Na}$ (mglg DM) & Ca (mglg DM) & K (mglg DM) & $P($ mglg DM) \\
\hline \multicolumn{5}{|l|}{ Leaves } \\
\hline Control & $0.48 \pm 0.03 \mathrm{~A}$ & $12.56 \pm 0.09 a$ & $11.41 \pm 0.94 \mathrm{~A}^{*}$ & $2.47 \pm 0.11 a^{*}$ \\
\hline $\mathrm{SA}(0.5 \mathrm{mM})$ & $0.83 \pm 0.07 \mathrm{~B}$ & $13.86 \pm 0.02 b$ & $19.27 \pm 1.10 \mathrm{~B}^{*}$ & $2.66 \pm 0.05 a^{*}$ \\
\hline $\mathrm{SA}(1 \mathrm{mM})$ & $0.92 \pm 0.01 C$ & $13.19 \pm 0.41 b$ & $15.03 \pm 0.37 C^{*}$ & $2.47 \pm 0.11 a^{*}$ \\
\hline $\mathrm{NaCl}$ & $18 \pm 1 \mathrm{D}$ & $9 \pm 0.68 c$ & $5 \pm 0.37 D^{*}$ & $0.73 \pm 0.22 b^{*}$ \\
\hline $\mathrm{NaCl}+\mathrm{SA}(0.5 \mathrm{mM})$ & $3.05 \pm 0.05 E$ & $14.79 \pm 0.37 d$ & $10.60 \pm 0.49 E^{*}$ & $1.42 \pm 0.03 c^{*}$ \\
\hline $\mathrm{NaCl}+\mathrm{SA}(1 \mathrm{mM})$ & $8.39 \pm 0.16 \mathrm{~F}$ & $11.50 \pm 0.77 e$ & $7.31 \pm 0.10 \mathrm{~F}^{*}$ & $0.59 \pm 0.11 b^{*}$ \\
\hline \multicolumn{5}{|l|}{ Roots } \\
\hline Control & $0.50 \pm 0.01 a$ & $8.41 \pm 0.07 \mathrm{~A}$ & $6.42 \pm 0.05 a^{*}$ & $1.01 \pm 0.01 \mathrm{~A}^{*}$ \\
\hline $\mathrm{SA}(0.5 \mathrm{mM})$ & $0.51 \pm 0.00 \mathrm{a}$ & $16.11 \pm 0.10 \mathrm{~B}$ & $12.84 \pm 0.02 b^{*}$ & $3.85 \pm 0.01 B^{*}$ \\
\hline $\mathrm{SA}(1 \mathrm{mM})$ & $0.90 \pm 0.08 b$ & $15.03 \pm 0.37 C$ & $8.87 \pm 0.02 c^{*}$ & $1.13 \pm 0.01 A^{*}$ \\
\hline $\mathrm{NaCl}$ & $24.33 \pm 0.51 c$ & $3.70 \pm 0.43 \mathrm{D}$ & $4.12 \pm 0.02 d^{*}$ & $0.53 \pm 0.11 C^{*}$ \\
\hline $\mathrm{NaCl}+\mathrm{SA}(0.5 \mathrm{mM})$ & $5.73 \pm 0.30 d$ & $9 \pm 0.20 \mathrm{E}$ & $8.60 \pm 0.20 c^{*}$ & $0.96 \pm 0.05 A^{*}$ \\
\hline $\mathrm{NaCl}+\mathrm{SA}(1 \mathrm{mM})$ & $10.67 \pm 0.57 \mathrm{e}$ & $6.43 \pm 0.40 \mathrm{~F}$ & $7.70 \pm 0.10 c^{*}$ & $0.61 \pm 0.12 D^{*}$ \\
\hline
\end{tabular}




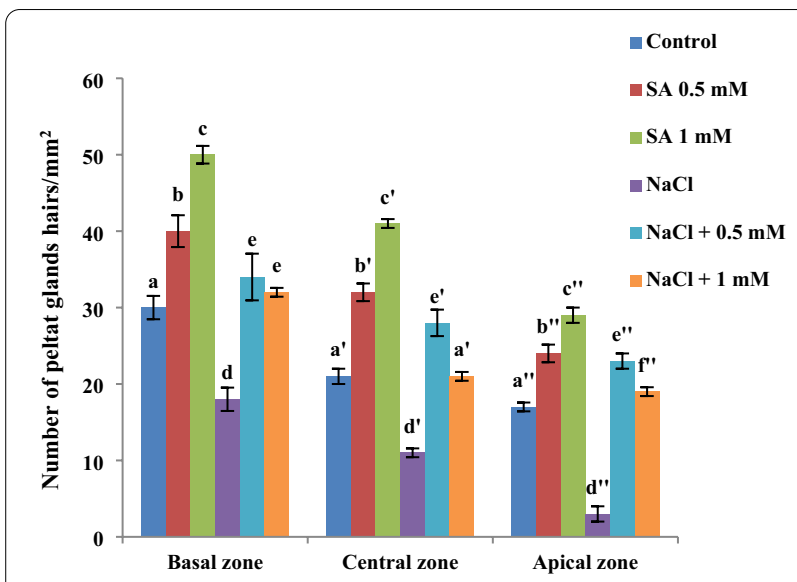

Fig. 3 Peltat glands abundance on the adaxial surface of S. officinalis leaves exposed to different SA treatment and saline stress. Different letters indicate statistically significant $(p \leq 0.05)$ differences among treatments

(Figs. 3 and 4b). This decrease reaches almost $40 \%$ at the basal level, $47 \%$ at the central level and $82 \%$ at the apical level compared to control plants. However, SA treatment in stressed plants reflect a very significant increase in the number of glands. This increase was greater at $0.5 \mathrm{mM}$ (Fig. 4c) which can reach $89 \%$ at the basal level, $154 \%$ at the central level and $667 \%$ at the apical level compared to unstressed plants.

\section{Glandular trichomes ultrastructure}

Observations by scanning electron microscopy showed that the control plants present two types of glands: the peltate and the capitate with the presence of protective hairs (Fig. 5a). These two types of glands differ in their morphology. The peltate glands were characterized with a short unicellular stalk and a broad and rounded head, while the peltate had a long stalk and a small head also rounded in shape. Stressed plants showed the same types of glands seen in controls. However, several abnormalities in the structure of the glands have been observed: the first anomaly consists of the presence of glandular structures (Figs. 5b and 6) characterized by deformities in the form of small pockets located on the head of the gland (Fig. 5b-e). These deformities can be one (Fig. 5b, c) or two (Fig. 5e) on the same gland. This type of deformation was the most frequently observed. The second, less frequent anomaly was that some glands lose their spherical characteristic and assume an ovoid shape (Fig. 5a). These abnormalities observed in the leaves of stressed plants disappear completely under SA treatment (Fig. 3c). However, salt stress had no significant effect on the diameter of the glands, the latter being around $80 \mu \mathrm{m}$ regardless of the conditions in which the plant was found (Fig. 4).

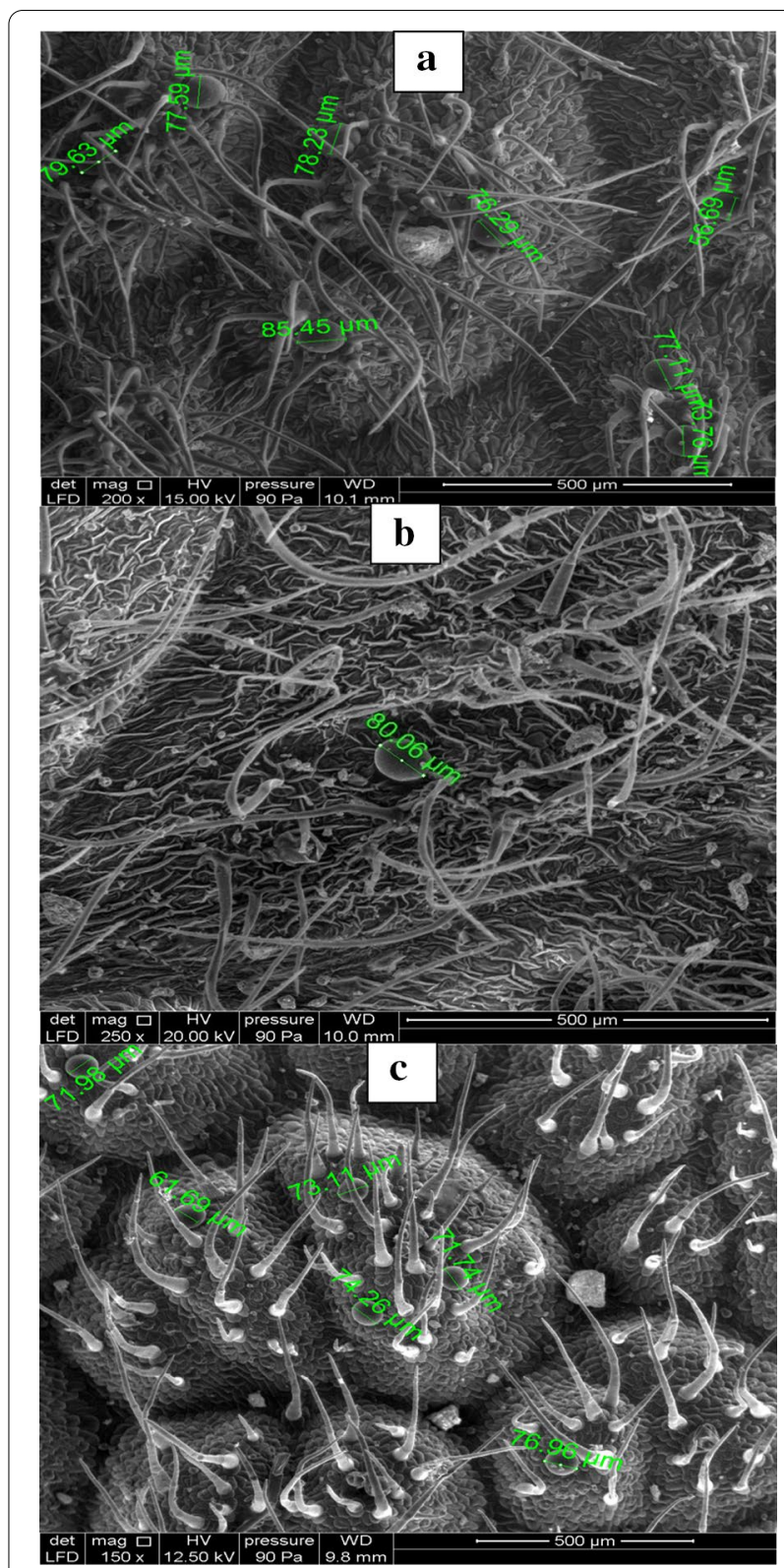

Fig. 4 Observation by environmental scanning electron microscopy in leaves of S. officinalis. Control (a), $\mathrm{NaCl}(\mathbf{b})$ and $\mathrm{NaCl}+\mathrm{SA} 0.5 \mathrm{mM}$

\section{Essential oil yield}

The essential oil yield was largely influenced by the different treatments (Table 2). In the absence of salt stress, spraying SA improved the essential oil yield of sage. This improvement was greater at the higher SA concentration and can reach $1.8 \%$ at a concentration of $1 \mathrm{mM}$, which mean an increase by $50 \%$ compared to the control. Salt stress decreased essential oil yield with 33\% compared to the control. On another hand, SA application on to stressed plants increased essential oils yield. These 


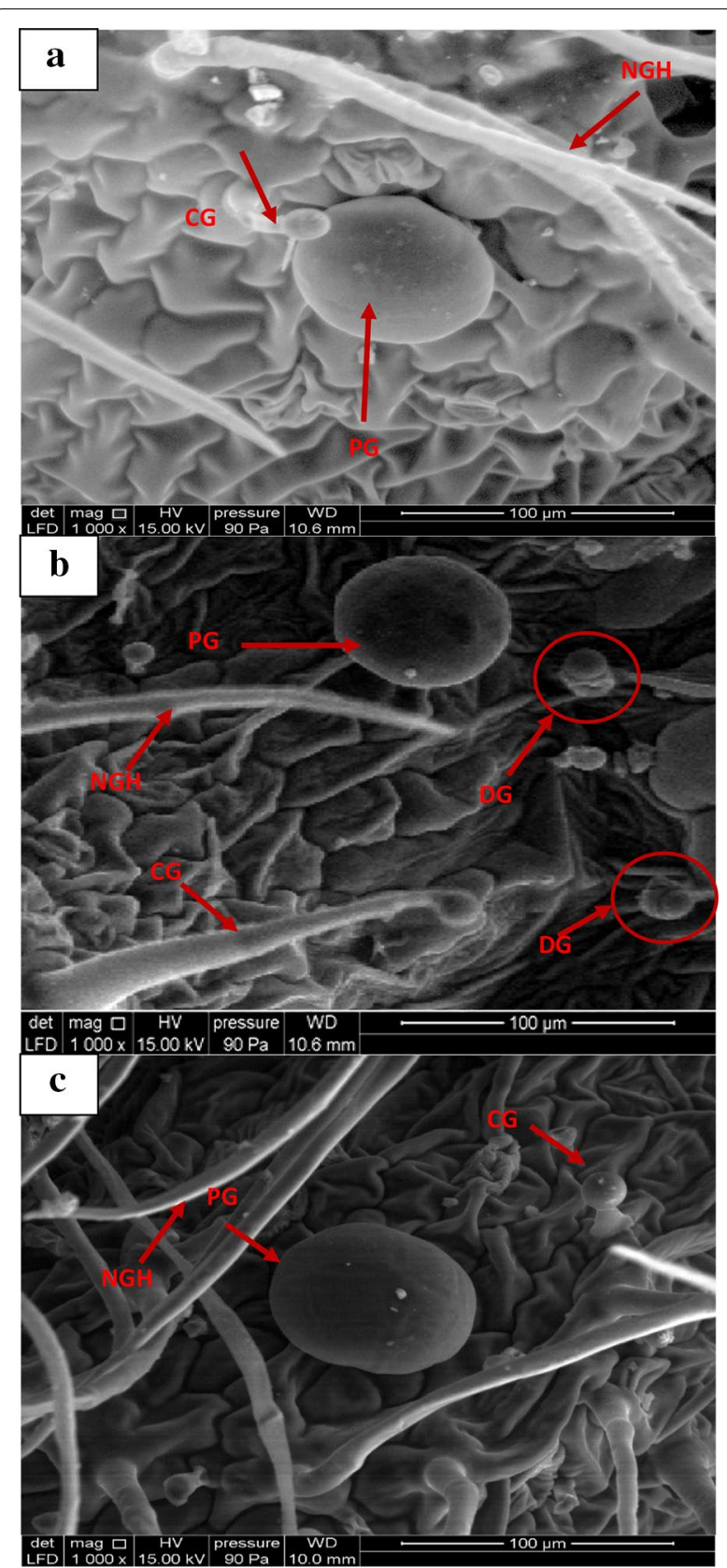

Fig. 5 Observation by environmental scanning electron microscopy of the adaxial of sage leaves (S. officinalis) from control (a), palnts traited with $\mathrm{NaCl}(\mathbf{b})$ and plants traited with $\mathrm{NaCl}+\mathrm{SA}$; $P G$ Peltate gland, NGH non-glandular hairs, CG capitates glands, DG deformed gland

increased can reach $112 \%$ when SA was used at $0.5 \mathrm{mM}$ and almost $62 \%$ when used at $1 \mathrm{mM}$.

\section{Essential oil composition}

The identified essential oil compounds of S. officinalis are listed in Table 2. Four categories of compounds were identified which were mainly hydrocarbon and oxygenated monoterpenes, also hydrocarbon and oxygenated sesquiterpenes, with different percentages depending on the treatments. Oxygenated monoterpenes represented the main family regardless of the treatment. The main compounds of this family were 1,8 -cineol, $\alpha$-thujone, and camphor, with a balance of disappearance and appearance of some compounds. In non-stress conditions, treatments with SA showed a variation in the composition of sage essential oil mainly at a concentration of $1 \mathrm{mM}$. The hydrocarbon monoterpenes increased from $14.66 \%$ in the control to $16.27 \%$ and $17.89 \%$ in plants treated with SA at 0.5 and $1 \mathrm{mM}$, respectively. However, these two concentrations caused a slight decrease in oxygenated monoterpenes. Furthermore, a positive effect of SA on hydrocarbon and oxygenated sesquiterpenes were detected. They were increased from $2.03 \%$ in control to $3.66 \%$ and $3.1 \%$ in plants treated with SA at $0.5 \mathrm{mM}$ and $1 \mathrm{mM}$, respectively. We noted also the appearance of another compounds under SA treatment like $\mathrm{L}$ - $\alpha$-terpineol, Pulegone and $\gamma$-Muurolene. Salt stress decreased hydrocarbon monoterpenes and oxygenated monoterpenes contents compared to the control with $34.11 \%$ and $1.83 \%$, respectively. Therefore, we noted a decrease in the content of the main compounds, camphor varied from 26.41 to $19.11 \%$, $\alpha$-thujone from 27.43 to $20.20 \%$ and 1,8-cineol from 14.92 to $10.00 \%$. On another hand, salt stress caused the appearance of thujanone $(15.73 \%)$ with high percentages. we noted also the appearance of another compounds under salt tress not detected in control plants like viridiflorol $(0.32 \%)$, caryophylladienol II $(0.38 \%)$, Geranyl isovalerate $(0.18 \%)$, $\beta$-Longipinene $(0.34 \%)$, borneol $(0.83 \%), \mathrm{L}-\alpha$-terpineol (1.58\%) Myrtenol (0.27\%), $\gamma$-Muurolene $(0.24 \%)$ and Pulegone $(0.45 \%)$. However, salt stress increased the hydrocarbon and oxygenated sesquiterpenes contents by $49.75 \%$ and $19.07 \%$, respectively, as compared to the control. In stressed plants, SA application increased hydrocarbon monoterpenes (with $24.84 \%$ at $0.5 \mathrm{mM}$ and $33.02 \%$ at $1 \mathrm{mM}$ ) and oxygenated monoterpenes (with $8.75 \%$ at $0.5 \mathrm{mM}$ and $2.69 \%$ at $1 \mathrm{mM}$ ) compared to the stressed plants untreated with SA. SA at $0.5 \mathrm{mM}$ increased the major compounds compared to the stressed plants untreated with SA: camphor varied from 10.00 to $14.00 \%$, $\alpha$-thujone from 20.20 to $25.38 \%$, thujanone from 15.73 to $16.62 \%$ and 1,8-cineol from 10.00 to $14.00 \%$. SA at $1 \mathrm{mM}$ increased content of camphor from 10.00 to $24.62 \%$, $\alpha$-thujone from 20.20 to $27.58 \%$ and 1,8 -cineol from 10.00 to $14.14 \%$. 


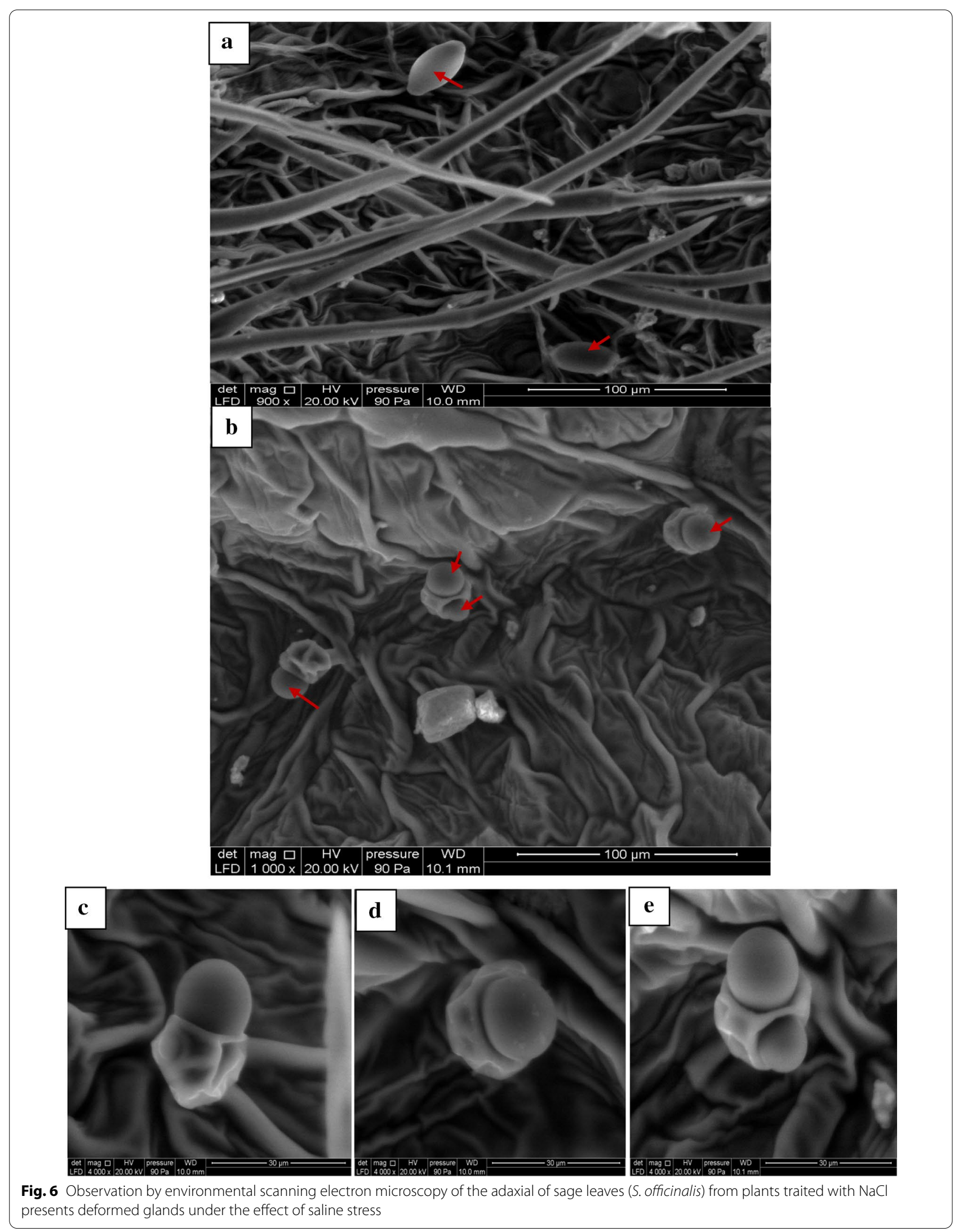


Table 2 Influence of SA and salt stress on essential oils yield and composition in S. officinalis

\begin{tabular}{|c|c|c|c|c|c|c|}
\hline & Control & $\mathrm{SA} 0.5 \mathrm{mM}$ & SA $1 \mathrm{mM}$ & $\mathrm{NaCl}$ & $\mathrm{NaCl}+\mathrm{SA} 0.5 \mathrm{mM}$ & $\mathrm{NaCl}+\mathrm{SA} 1 \mathrm{mM}$ \\
\hline Oils content (\%) & $1.2 \pm 0.01 a$ & $1.5 \pm 0.01 b$ & $1.8 \pm 0.1 \mathrm{C}$ & $0.8 \pm 0.1 d$ & $1.7 \pm 0.1 \mathrm{e}$ & $1.3 \pm 0.1 \mathrm{f}$ \\
\hline Components & Peak area \% & & & & & \\
\hline \multicolumn{7}{|c|}{ Hydrocarbon monoterpenes } \\
\hline Tricyclene & 0.21 & 0.24 & 0.26 & nd & nd & nd \\
\hline a-Pinene & nd & 7.44 & 2.00 & 2.09 & 2.89 & 2.93 \\
\hline$\beta$-Terpinene & 6.43 & nd & nd & 2.00 & 2.69 & 2.88 \\
\hline Camphene & 4.30 & 4.62 & 5.30 & nd & 4.07 & nd \\
\hline$\beta$-Pinene & 1.85 & 2.24 & nd & 2.09 & 1.93 & 2.54 \\
\hline$\beta$-Myrcene & 1.02 & 1.11 & 1.20 & 1.92 & nd & 1.21 \\
\hline a-Terpinene & 0.12 & nd & nd & $\operatorname{Tr}$ & 0.20 & 1.76 \\
\hline Terpinolene & 0.25 & 0.36 & 0.40 & 0.88 & 0.16 & 0.85 \\
\hline a-Ocimene & 0.10 & nd & nd & nd & nd & nd \\
\hline$\beta$-Ocimene & 0.17 & 0.11 & $\mathrm{Nd}$ & nd & 0.12 & nd \\
\hline Y-Terpinene & nd & nd & 0.31 & 0.68 & nd & 0.68 \\
\hline 2-Carene & nd & 0.15 & 0.12 & nd & nd & nd \\
\hline Cis-Sabinene hydrate & 0.21 & nd & nd & nd & nd & nd \\
\hline Pseudolimonene & nd & nd & 8.30 & nd & nd & nd \\
\hline Total (\%) & 14.66 & 16.27 & 17.90 & 9.66 & 12.06 & 12.85 \\
\hline \multicolumn{7}{|c|}{ Oxygenated monoterpenes } \\
\hline 1,8-Cineole & 14.92 & 15.06 & 15.57 & 10.00 & 14.00 & 14.14 \\
\hline Thujanone & nd & nd & nd & 15.73 & 16.62 & 6.00 \\
\hline Thujanol & 0.10 & nd & nd & 0.72 & nd & 0.23 \\
\hline$\beta$-Terpineol & 0.12 & nd & nd & 0.15 & 0.19 & 0.22 \\
\hline$\beta$-Thujone & 2.90 & 3.42 & 3.50 & 1.55 & 0.40 & 0.12 \\
\hline a-Thujone & 27.43 & 22.22 & 21.11 & 20.20 & 25.38 & 27.58 \\
\hline Camphor & 26.41 & 27.44 & 27.81 & 19.11 & 23.05 & 24.62 \\
\hline Thujol & 0.64 & nd & 0.32 & nd & nd & nd \\
\hline Endo-borneol & 0.62 & 1.47 & 2.63 & 1.35 & 0.73 & 1.07 \\
\hline Borneol & nd & nd & nd & 0.83 & nd & 0.48 \\
\hline Bornyl acetate & 1.83 & nd & 0.90 & 1.41 & nd & 0.51 \\
\hline Terpinen-4-ol & 0.87 & nd & 0.80 & 0.88 & nd & 0.90 \\
\hline L-a-Terpineol & nd & 0.40 & 0.66 & 1.58 & 0.40 & 0.35 \\
\hline Myrtenol & nd & nd & nd & 0.27 & 0.26 & 0.24 \\
\hline Estragol & 0.59 & 0.82 & 0.91 & nd & nd & nd \\
\hline Pulegone & nd & 0.10 & 0.11 & 0.45 & 0.11 & 0.16 \\
\hline Costol & nd & nd & nd & 0.38 & nd & nd \\
\hline Totale (\%) & 76 & 71.73 & 74.44 & 74.61 & 81.14 & 76.62 \\
\hline \multicolumn{7}{|c|}{ Hydrocarbon sesquiterpenes } \\
\hline Cariophyllene & 1.11 & 1.82 & 1.4 & 1.29 & 2.24 & 1.30 \\
\hline Humulene & 0.92 & 1.57 & 1.6 & 1.00 & 0.13 & 1.09 \\
\hline Y-Muurolene & nd & 0.14 & 0.10 & 0.24 & 0.18 & 0.16 \\
\hline Cadinene & nd & 0,13 & nd & nd & nd & nd \\
\hline$\beta$-Longipinene & nd & nd & nd & 0.34 & 0.30 & 0.17 \\
\hline Germacrene-D & $\operatorname{Tr}$ & nd & 0.12 & 0.17 & nd & 0.14 \\
\hline Total (\%) & 2.03 & 3.66 & 3.1 & 3.04 & 2.88 & 2.86 \\
\hline \multicolumn{7}{|c|}{ Oxygenated sesquiterpenes } \\
\hline Geranyl isovalerate & nd & nd & nd & 0.18 & nd & 0.13 \\
\hline Sabinol isovalerate & 0.31 & nd & 0.17 & nd & 0.36 & 0.38 \\
\hline Caryophyllene oxide & 0.98 & 0.79 & 0.72 & 0.65 & 0.71 & 0.29 \\
\hline
\end{tabular}


Table 2 (continued)

\begin{tabular}{lllllll}
\hline & Control & SA 0.5 mM & SA 1 mM & NaCl & NaCl+SA 0.5 mM & $\mathrm{NaCl}+\mathrm{SA} 1 \mathrm{mM}$ \\
\hline Humulene epoxide II & 0.65 & 0.78 & 0.75 & 0.49 & 0.96 & 1.30 \\
Viridiflorol & nd & 2.81 & 2.70 & 0.32 & 0.71 & 0.29 \\
Caryophylladienol II & nd & nd & nd & 0.38 & 0.24 & 0.17 \\
B-Santalol & nd & nd & nd & 0.29 & 0.30 & 0.22 \\
Total (\%) & 1.94 & 4.38 & 4.34 & 2.31 & 2.58 & 2.78 \\
Total identified (\%) & 94.61 & 96.04 & 99.77 & 89.62 & 98.66 & 95.11 \\
\hline
\end{tabular}

The values followed by different letters are significantly different $(P \leq 0.05)$

$S A$ salicylic acid, $n d$ not detected, $\operatorname{tr}$ trace $(<0.1 \%)$

\section{Discussion}

Our results showed the negative effect of salt stress on the growth of the aerial and root part of S. offcinalis, confirming the results of Aftab et al. [1] in Artemisia annua L. This reduction in growth can be attributed to the toxicity of $\mathrm{Na}^{+}$ions accumulated in plants $[1,11]$ which leads to a nutritional imbalance $[30,37,43]$. These high concentrations of $\mathrm{Na}^{+}$accumulated in the plant decreased the $\mathrm{Ca}$, $\mathrm{P}$ and $\mathrm{K}$ levels. In addition, our results showed that SA treatment mainly at $0.5 \mathrm{mM}$ stimulated the growth of $S$. officinalis plants. This improvement in growth was confirmed by an improvement of mineral element contents ( $\mathrm{K}, \mathrm{P}$ and $\mathrm{Ca}$ ). Other authors had also linked the stimulation of growth under SA treatment to decrease the accumulation of toxic $\mathrm{Na}^{+}$concentrations and improvement of mineral nutrition [2, 3, 5, 20, 21]. In addition, Shakirova et al. [48] reported that SA stimulates cell division in the apical meristem which improves plant growth. Some Authors showed the effect of SA on improving indole 3 -acetic acid (AIA) and abscisic acid evels, which play a role in the regulation of genes and activity of antioxidant enzymes [9] and stomata movement [52]. Shakirova et al. [47] concluded that endogenous ABA is a hormonal intermediate to trigger defense reactions under the influence of SA. Tahjib et al. [49] attributed the positive effect of SA under salinity to the ability of SA (1) to improve growth by stimulating photosynthetic capacity, (2) induction of antioxidant enzyme activity to reduce oxidative damage (3) protection of parameters contributing to performance. The reduction in growth may also be linked to the decrease in the concentrations of chlorophyll pigments confirming the results of Hashimi et al. [24] and Ahmad et al. [3]. The decrease in chlorophyll contents could be due to the instability of the protein complexes responsible for the chlorophyll synthesis and/or to the increased of chlorophyllase activity (chlorophyll degradation) [27]. Furthermore, the treatment of these stressed plants with SA mainly at $0.5 \mathrm{mM}$ stimulated the synthesis of the pigments. These results were consistent with those of Noreen and Ashraf [39] who attributed the stimulation of growth by SA to the stimulation of photosynthetic capacity. This stimulation could be linked also to the activation of RuBisCO, PEP carboxylase and the chlorophyll biosynthesis under SA treatment [33]. Essential oil synthesis was inhibited by salt stress. This result confirms the work carried out on Mentha suaveolens [30] and on Mentha piperita [32] which showed that $\mathrm{NaCl}$ at $150 \mathrm{mM}$ seriously affected essential oil synthesis. This inhibition of essential oil synthesis can be attributed to $\mathrm{Na}^{+}$ions toxicity on the cell membrane, cytoplasm, cell nucleus and the availability of certain essential nutrients to the plant [30]. This negative effect may also be due to the inhibition of cytokinin delivery to shoots from the roots and to the altered ratio between cytokinin and abscisic acid [17]. In addition, spraying SA on stressed plants improved the essential oil yield. Khanam and Mohammad [32] showed that $\mathrm{NaCl}-\mathrm{SA}$ interaction allows obtaining the best yield. These authors had linked also this improvement to the increase in NPK contents and to the increase in the number and diameter of peltate glands under the SA effect. Croteau [15] and Prakasa et al. [41] also suggested that the number of secretory glands is one of the factors that influence the essential oil yield. In this light, our data showed the negative effect of salt stress on glands density. These results agree with those of Khanam and Mohammad [32] in Mentha piperita. This increase in glands density was accompanied by an increase in essential oil contents. In addition, this increase in glands density can also be linked to changes in the hormonal profile [12, 25], because an increase in auxins and gibberellins levels have been recorded under SA treatment [24, 50]. Yadegari [53] showed that at low concentrations, SA have had a stimulating effect while concentration at higher concentrations, it reduced essential oils content in S. officinallis.

Concerning the chemical composition of essential oil, we observed many qualitative and quantitative variations depending on the treatments. These modifications result in the appearance or disappearance of some compounds and changes in the contents of pre-existing compounds. S. officinalis is one of the most important 
medicinal and aromatic plants, with antioxidant, antimicrobial, spasmolytic, astringent, anti hidrotic and specific sensorial properties. Its essential oil is mainly composed of 1,8-cineole, thujone and camphor are responsible for some of these effects. Russo et al. [45] other showed the importance effect of the $\alpha$-thujone and camphor in anticancer activity of S. officinalis In our study we found that salt stress decreased the content of these major compounds; 1,8 -cineol, varied from 14.92 to $10.00 \%$ camphor from 26.41 to $19.11 \%$ and $\alpha$-thujone from 27.43 to $20.20 \%$. We noted the appearance of a new major molecule (its content 15.73\%). we noted also the appearance of another compounds under salt tress not detected in control plants like viridiflorol (0.32\%), caryophylladienol II (0.38\%), Geranyl isovalerate $(0.18 \%), \beta$-Longipinene $(0.34 \%)$, borneol (0.83\%), L- $\alpha$-terpineol (1.58\%) Myrtenol $(0.27 \%)$ and Pulegone $(0.45 \%)$. However, spraying SA increased the content of the major compounds affected by salt stress. The best results were obtained in plants sprayed with $1 \mathrm{mM}$, under this concentration we found that the 1,8-cineol, varied from 10.00 to $14.14 \%$ camphor from 19.11 to $24.62 \%$ and $\alpha$-thujone from 20.20 to $27.58 \%$. Similar results were observed by Pirbalouti et al. [40] and Mohammadi et al. [36], which indicated that foliar spraying with SA on thyme reduced the effect of water stress on the concentration of the main compound of the essential oil, and increased the concentrations of p-cymene, $\alpha$-pinene, $\alpha$-thujone and carvacrol [40]. In S. officinalis. Yadegari [53] showed in SA-treated plants produced greater quantities of camphene, 1,8-cineole, thujone, camphor, borneol, borneol acetate, carvacrol and thymol in no stress condition. Sirvent and Gibson showed that SA can convert thymol to carvacrol and play an important role in the activation of various plant defense responses such as the biosynthesis of special secondary metabolites that act as phytoalexins. However, Ahmad et al. [2] demonstrated that high concentrations of cadmium caused a decrease in menthone and menthol concentrations. Whereas treatment with SA increased the levels of these two compounds in peppermint. This effect can be attributed to the beneficial effect of SA on the metabolism and enzymatic activities responsible for the biosynthesis of mono and sesquiterpenes [2, 24, 27, 44]. Moreover, Rowshan et al. [44] demonstrated that the essential oil yield of S. macrosiphon increased after the application of SA at $400 \mathrm{mg} \mathrm{l}^{-1}$ with increased levels of hexylisobutanate and linalool and the appearance of new compounds such as 1,8-cineol and the $\alpha$-pinene. In fennel, Hashmi et al. [24] also illustrated that SA at $10^{-4} \mathrm{M}$ increased essential oil yield and contents of components.
Microscopic observations on $S$. officinalis leaves showed the presence of peltate and capitate glands and non-glandular trichomes (protective hairs), which is confirmed and detected by many authors, Es-sbihi et al. [18] and Hazzoumi et al. [26]. The capitate glands: ("glandular trichomes short-term", as indicated by Werker et al. [51]), present the main secretory hairs for some protective substance, release their secretory material shortly after their production and serve to protect young organs. There was no evidence of accumulation of secretion product in the subcuticular space [10].

Corsi and Bottega [13] showed that S. officinalis has four types of capitate glands which differ in structure, location, secretory material and mode of secretion:

Type I with a short unicellular or bicellular stalk and a large unicellular or bicellular secretory head and characterized by the absence of a subcuticular chamber. The secretory material slowly exudes through the intact cuticle and is released suddenly if the cuticle is ruptured.

Type II is very small with a unicellular stem and a secretory head with a subcuticular chamber. The secretory material probably exudes through a single pore.

Type III is large, characterized by a long stem, a neck cell, and a single-celled head.

Peltate glands: glandular trichomes long-term, as indicated by Werker et al. [51] in which secretory material gradually accumulates under an elevated cuticle and which serves to protect mature organs. In the flower, these glands play the role of protection against herbivores and the attraction of pollinators and present the main structure for terpenoids accumulation and secretion.

The leaves of the stressed plants showed the presence of glands exhibiting the same characteristics encountered in the control. Nevertheless, under these conditions of salt stress, we were able to highlight the presence of glandular structures, never observed in control plants or treated with SA. These glands present on their surface deformations in the form of small pockets. The presence of one or more pockets on the same gland has been observed. In addition, some of the glands sometimes take on an ovoid shape different from the spherical shape usually seen in plants. Since such structures have never been observed in unstressed plants or in plants that have been treated with SA, we can hypothesize that these anomalies appear as a result of external toxicity. In our case an excess of salt could be at the origin of these deformations. The same structures have been observed by Es-sbihi et al. [19] in S. officinalis cultivated under excess zinc. Treatment of plants with SA under this metallic stress does not showed the presence of these deformities. 


\section{Conclusion}

In S. officinalis, salt stress inhibited the growth, chlorophyll and essential oil synthesis. However, SA application (especially at $0.5 \mathrm{mM}$ ), reduced the $\mathrm{Na}^{+}$contents in the plant and improved growth, increased the nutrients $(\mathrm{Ca}, \mathrm{K}$ and P), chlorophyll, essential oil contents and the peltate glands density.

The histological study of the leaves of plants cultivated under saline stress highlighted two morphological anomalies: the first was represented by the presence of glands presenting deformations in the form of pockets located on the surface of the head. The second anomaly was the presence of glands with an ovoid shape different from the spherical shape usually seen in unstressed plants. However, these anomalies tend to disappear by foliar spraying of SA $(0.5$ and $1 \mathrm{mM}$ ) showing the restorative effect of SA in case of salt stress.

\section{Abbreviations}

SA: Salicylic acid; DM: Dry matter; DAT: Days of plants transplantation.

\section{Acknowledgements}

Not applicable.

\section{Authors' contributions}

All authors of this research paper have directly participated in planning, execution and analysis of the study. All authors read and approved the final manuscript.

\section{Funding}

The authors have not received any funding.

\section{Availability of data and materials}

Additional data may be availed on request to the authors through the corresponding author. We take legal responsibility for information, used procedures, data and results.

\section{Declarations}

Ethics approval and consent to participate

This research work meets all the ethical guidelines, adhering to the legal requirements of my country.

\section{Consent for publication}

The authors confirm that there is no conflict of interest and agree with submission of the manuscript to your journal.

\section{Competing interests}

The authors declare that they have no competing interests.

\section{Author details}

${ }^{1}$ Laboratory of Microbial Biotechnology and Bioactive Molecules, Faculty of Science and Technology Fez, Sidi Mohamed Ben Abdellah University, Road of Imouzzer, B.P. 2202, Fez, Morocco. ${ }^{2}$ Green Biotechnology Laboratory, Moroccan Foundation for Advanced Science, Innovation and Research (MAS(IR), Rabat Design Center, Madinat Al Irfan, Rabat, Morocco.

Received: 4 February 2021 Accepted: 16 March 2021

Published online: 29 April 2021

\section{References}

1. Aftab T, Khan MMA, da Silva JAT, Idrees M, Naeem M. Role of salicylic acid in promoting salt stress tolerance and enhanced artemisinin production in Artemisia annua L. J Plant Growth Regul. 2011;30:425-35.

2. Ahmad P, Alyemeni MN, Ahanger MA, Egamberdieva D, Wijaya L, Alam P. Salicylic Acid (SA) Induced Alterations in Growth, Biochemical Attributes and Antioxidant Enzyme Activity in Faba Bean (Vicia faba L.) Seedlings under NaCl Toxicity. Russian J Plant Physiol. 2018;65(1):104-14.

3. Ahmad F, Singh A, Kamal A. Ameliorative effect of salicylic acid in salinity stressed Pisum sativum by improving growth parameters, activating photosynthesis and enhancing antioxidant defense system. Biosci Biotechnol Res Commun. 2017;10:481-9.

4. Akram S, Siddiqui MN, Hussain BMN, Bari MA, Mostofa MG, Hossain MA, Tran LSP. Exogenous glutathione modulates salinity tolerance of soybean [Glycine max (L.) Merrill] at reproductive stage. J Plant Growth Regul. 2017:36:877-88.

5. Arfan M, Habib R, Muhammad A. Does exogenous application of salicylic acid through the rooting medium modulate growth and photosynthetic capacity in two differently adapted spring wheat cultivars under salt stress? J Plant Physiol. 2007;164(6):685-94.

6. Ashraf MPJC, Harris PJC. Potential biochemical indicators of salinity tolerance in plants. Plant Sci. 2004;166:3-16.

7. Ashraf MA, lqbal M, Rasheed R, Hussain I, Riaz M, Arif MS. Environmental stress and secondary metabolites in plants: an overview. In: Plant metabolites and regulation under environmental stress. Academic Press; 2018. p. 153-67.

8. Azeem M, Ahmad R. Foliar application of some essential minerals on tomato (Lycopersicon esculentum) plant grown under two different salinity regimes. Pak J Bot. 2011;43:1513-20.

9. Bari $\mathrm{R}$, Jones JDG. Role of plant hormones in plant defence responses. Plant Mol Biol. 2009;69(4):473-88.

10. Bisio A, Corallo A, Gastaldo P, Romussi G, Ciarallo G, Fontana N, Profumo P. Glandular Hairs and Secreted Material in Salvia blepharophylla Brandegee ex Epling Grown in Italy. Ann Bot. 1999;83:441-52.

11. Bouchoukh I. Comportement écophysiologique de deux Chénopodiacées des genres Atriplex et Spinacia soumises au stress salin. 2010.

12. Copetta A, Lingua G, Bert G. Effects of three AM fungi on growth, distribution of glandular hairs, and essential oil production in Ocimum basilicum L. var. Genovese. Mycorrhiza. 2006;16:485-94.

13. Corsi G, Bottega S. Glandular hairs of Salvia officinalis: new data on morphology, localization and histochemistry in relation to function. Ann Bot. 1999;84:657-64.

14. Cottenie A, Verloo M, Kiekens L, Velghe G, Camerlynck R. Chemical analysis of plant and soil laboratory of analytical and agrochemistry. Belgium: State University Ghent; 1982. p. 100-29.

15. Croteau R. Biosynthesis and catabolism of monoterpenoids. Chem Rev. 1987;87:929-54.

16. Dubey SK. Microbial ecology of methane emission in a rice agroecosystem. Appl Ecol Environ Res. 2005;3:1-27.

17. El-Keltawi NE, Croteau R. Salinity depression of growth and essential oil formation in spearmint and marjoram and its reversal by foliar applied cytokinin. Phytochemistry. 1987;26:1333-4.

18. Es-sbihi FZ, Hazzoumi Z, Benhima R, Joutei KA. Effects of salicylic acid on growth, mineral nutrition, glandular hairs distribution and essential oil composition in Salvia officinalis L. grown under copper stress. Environ Sustain. 2020;3:199-208.

19. Es-sbihi FZ, Hazzoumi Z, Joutei KA. Effect of salicylic acid foliar application on growth, glandular hairs and essential oil yield in Salvia officinalis L. grown under zinc stress. Chem Biol Technol Agric. 2020;7(1):1-11.

20. Faghih S, Ghobadi C, Zarei A. Response of strawberry plant CV. 'Camarosa' to salicylic acid and methyl jasmonate application under salt stress condition. J Plant Growth Regul. 2017;36:651-9.

21. Gautam S, Singh PK. Salicylic acid-induced salinity tolerance in corn grown under $\mathrm{NaCl}$ stress. Acta Physiol Planta. 2009;31:1185.

22. Grzeszczuk M, Salachna P, Meller E. Changes in photosynthetic pigments, total phenolic content, and antioxidant activity of Salvia coccinea Buc'hoz Ex Etl. induced by exogenous salicylic acid and soil salinity. Molecules. 2018:23(6):1296.

23. Gunes A, Inal A, Alpaslan M, Eraslan F, Bagci EG, Cicek N. Salicylic acid induced changes on some physiological parameters symptomatic for 
oxidative stress and mineral nutrition in maize (Zea mays L.) grown under salinity. J Plant Physiol. 2007;164(6):728-36.

24. Hashmi N, Khan MMA, Idrees M, Aftab T. Exogenous salicylic acid stimulates physiological and biochemical changes to improve growth, yield and active constituents of fennel essential oil. Plant growth Regul. 2012;68:281-91.

25. Hazzoumi Z, Moustakime Y, Amrani JK. Effect of arbuscular mycorrhizal fungi and water stress on ultrastructural change of glandular hairs and essential oil compositions in Ocimum gratissimum. Chem Chem Biol Technol Agric. 2017;4(1):20.

26. Hazzoumi Z, Moustakime Y, Joutei KA. Essential oil and glandular hairs: diversity and roles. In: Essential oils-oils of nature. IntechOpen; 2019.

27. Idrees M, Naeem M, Aftab T, Khan MMA, Moinuddin. Salicylic acid mitigates salinity stress by improving antioxidant defense system and enhances vincristine and vinblastine alkaloids production in periwinkle (Catharanthus roseus). Acta Physiol Planta. 2011;33:987-99.

28. Jini D, Joseph B. Physiological mechanism of salicylic acid for alleviation of salt stress in rice. Rice Sci. 2017;24(2):97-108.

29. Joseph B, Jini D, Sujatha S. Insight into the role of exogenous salicylic acid on plants grown under salt environment. Asian. J Crop Sci. 2010;2:(4):226-35.

30. Kasrati A, Jamali CA, Bekkouche K, Wohlmuth H, Leach D, Abbad A. Plant growth, mineral nutrition and volatile oil composition of Mentha suaveolens timija cultivated under salt stress conditions. Ind Crops Prod. 2014;59:80-4

31. Khan MIR, Syeed S, Nazar R, Anjum NA. An insight into the role of salicylic acid and jasmonic acid in salt stress tolerance. In: Phytohormones and abiotic stress tolerance in plants. Berlin: Springer; 2012. p. 277-300.

32. Khanam D, Mohammad F. Plant growth regulators ameliorate the ill effect of salt stress through improved growth, photosynthesis, antioxidant system, yield and quality attributes in Mentha piperita L. Acta Physiol Planta. 2018:40:188.

33. Mateo A, Funck D, Mühlenbock P, Kular B, Mullineaux PM, Karpinski S. Controlled levels of salicylic acid are required for optimal photosynthesis and redox homeostasis. J Experim Botany. 2006:57:1795-807.

34. Mckinney G. Absorption of light by chlorophyll solutions. J Biol Chem. 1941;140:315-32.

35. Miura K, Tada Y. Regulation of water, salinity, and cold stress responses by salicylic acid. Front Plant Sci. 2014;5:4.

36. Mohammadi H, Amirikia F, Ghorbanpour M, Fatehi F, Hashempour H. Salicylic acid induced changes in physiological traits and essential oil constituents in different ecotypes of Thymus kotschyanus and Thymus vulgaris under well-watered and water stress conditions. Industrial Crops and Products. 2019;129:561-74.

37. Munns R. Comparative physiology of salt and water stresse. Plant Cell Environ. 2002;25(2):239-50.

38. Nie W, Gong B, Chen Y, Wang J, Wei M, Shi Q. Photosynthetic capacity, ion homeostasis and reactive oxygen metabolism were involved in exogenous salicylic acid increasing cucumber seedlings tolerance to alkaline stress. Sci Hortic. 2018;235:413-23.

39. Noreen S, Muhammad A. Alleviation of adverse effects of salt stress on sunflower (Helianthus annuus L.) by exogenous application of salicylic acid: growth and photosynthesis. Pak J Bot. 2008;40(4):1657-63.
40. Pirbalouti AG, Samani MR, Hashemi M, Zeinali H. Salicylic acid affects growth, essential oil and chemical compositions of thyme (Thymus daenensis Celak ) under reduced irrigation. Plant Growth Regul. 2014;72(3):289-301.

41. Prakasa REV, Ganesha RRS, Ramesh S. Seasonal variation in oil content and its composition in two chemotypes of scented geranium (Pelargonium sp.). J Essent Oil Res. 1995;7:159-63.

42. Rady MM, Taha RS, Semida WM, Alharby HF. Modulation of salt stress effects on Vicia faba $\mathrm{L}$. plants grown on a reclaimed-saline soil by salicylic acid application. Roman Agric Res. 2017;34:175-85.

43. Rashad RT, Hussien RA. A comparison study on the effect of some growth regulators on the nutrients content of maize plant under salinity conditions. Ann Agric Sci. 2014;59(1):89-94.

44. Rowshan V, Khoi MK, Javidnia K. Efects of salicylic acid on quality and quantity of essential oil components in Salvia macrosiphon. J Biol Environ Sci. 2010;4:77-82.

45. Russo A, et al. Chemical composition and anticancer activity of essential oils of Mediterranean sage (Salvia officinalis L.) grown in different environmental conditions. Food Chem Toxicol. 2013;55:42-7.

46. Sahar K, Amin B, Taher NM. The salicylic acid effect on the Salvia officianlis L. sugar, protein and proline contents under salinity $(\mathrm{NaCl})$ stress. J Stress Physiol Biochem. 2011;7(4):80-7.

47. Shakirova FM, Bezrukova MV, Yuldashev RA, Fatkhutdinova AR, Murzabaev AR. Involvement of lectin in the salicylic acid-induced wheat tolerance to cadmium and the role of endogenous ABA in the regulation of its level. Doklady Biol Sci. 2013;448(1):49-51.

48. Shakirova FM, Sakhabutdinova RA, Bezrukova MV, Fatkhutdinova RA, Fatkhutdinova DR. Changes in the hormonal status of wheat seedlings induced by salicylic acid and salinity. Plant Sci. 2003;164(3):317-22.

49. Tahjib M, Siddiqui MN, Sohag AAM, Sakil MA, Rahman MM, Polash MAS, Tran LSP. Salicylic acid-mediated enhancement of photosynthesis attributes and antioxidant capacity contributes to yield improvement of maize plants under salt stress. J Plant Growth Regul. 2018;37(4):1318-30.

50. Tomaszewski M, Thimann KV. Interactions of phenolic acids, metallic ions and chelating agents on auxin-induced growth. Plant Physiol. 1966:41:1443-54.

51. Werker E, Putievsky E, Ravid U, Dudai N, Katzir I. Glandular hairs and essential oil in developing leaves of Ocimum basilicum L. (Lamiaceae). Ann Bot. 1993;71:43-50.

52. Wilkinson S, Davies WJ. Drought, ozone, ABA and ethylene: new insights from cell to plant to community. Plant Cell Environ. 2010;33(4):510-25.

53. Yadegari M. Foliar application effects of salicylic acid and jasmonic acid on the essential oil composition of Salvia officinalis. Turk J Biochem. 2018;43(4):417-24.

\section{Publisher's Note}

Springer Nature remains neutral with regard to jurisdictional claims in published maps and institutional affiliations.

\section{Submit your manuscript to a SpringerOpen ${ }^{\circ}$ journal and benefit from:}

- Convenient online submission

- Rigorous peer review

- Open access: articles freely available online

- High visibility within the field

- Retaining the copyright to your article

Submit your next manuscript at $\boldsymbol{\nabla}$ springeropen.com 